\title{
HEMOGLOBIN LEVELS AFTER CONSUMING THE INITIAL PHASE OF ANTITUBERCULAR DRUGS
}

\author{
SUSIWATI ${ }^{1 *}$, ZAMHARIRA MUSLIM $^{2}$
}

${ }^{1}$ Department of Health Analyst, Politeknik Kesehatan Kemenkes Bengkulu, Bengkulu, Indonesia. ${ }^{2}$ Department of Pharmacy, Politeknik Kesehatan Kemenkes Bengkulu, Bengkulu, Indonesia. Email: susi7925@yahoo.com

Received: 18 November 2018, Revised and Accepted: 25 April 2019

ABSTRACT

Objective: This study aims to determine the condition of the hemoglobin ( $\mathrm{Hb}$ ) level after the initial phase of antitubercular drug usage.

Methods: This research method used a descriptive survey design with the accidental sampling method. The sample of this study was 38 patients who met the inclusion criteria of the study. The sample was measured by Coulter Act-Diff Hematology Analyzer.

Results: This study shows the initial phase of antitubercular drugs (ATD) usage caused an abnormal hemoglobin level of 22 patients (58\%) and 16 patients (42\%) have a normal level. There are $12(32 \%)$ male and $10(26 \%)$ female patients have an abnormal level of Hb. The average of Hb level in tuberculosis (TB) patients is 12.42 (male) and 11.89 (female). This study also shows the correlation between body mass index with a Hb level of TB patient $(\mathrm{p}=0.001)$

Conclusion: Hb levels in TB patients who consumed the initial phase of ATD were found to be mostly under normal.

Keywords: Tuberculosis, Hemoglobin, Antitubercular drugs, Initial phase.

(C) 2019 The Authors. Published by Innovare Academic Sciences Pvt Ltd. This is an open access article under the CC BY license (http://creativecommons. org/licenses/by/4. 0/) DOI: http://dx.doi.org/10.22159/ajpcr.2019.v12i6.30847

\section{INTRODUCTION}

Tuberculosis (TB) is an infectious disease caused by Mycobacterium TB. TB is one of the top 10 causes of death and the leading cause of a single infectious agent. In 2017, TB causes an estimated of 1, 3 million deaths among HIV-positive people. There were cases in all countries and age groups, but overall $90 \%$ were adults (aged $\geq 15$ years), $9 \%$ were people living with HIV ( $72 \%$ in Africa), and two-thirds were in eight countries: India $(27 \%)$, China (9\%), Indonesia (8\%), the Philippines $(6 \%)$, Pakistan (5\%), Nigeria (4\%), Bangladesh (4\%), and South Africa (3\%) [1]. Current therapy management of TB is inadequate due to the lengthy course of treatment, drug-related side effects and ill-planned therapy [2]. Many research related to the medicinal properties of the plants, when researched through modern scientific methods, may prove to have enormous potential in the discovery of newer and more efficacious antitubercular medicines [3].

The spread of pulmonary TB from one patient to another occurs through the infectious air that can come out with coughing, sneezing, and talking [4]. The source of infection is the lung TB patients who cough sputum, where the sputum smear examination is generally found positive acid-fast bacilli. An intensive 2-month initial phase of TB treatment was performed by administering antitubercular drugs (ATD) consisting of isoniazid, pyrazinamide, rifampicin, and ethambutol [5]. The hematologic examination includes hemoglobin $(\mathrm{Hb})$, leukocyte count, erythrocyte count, platelet count, hematocrit, and blood capillary examination may be indicative of complications or an ATD complication.

Anemia is a major feature in patients with bacterial infections, especially infections that last $>1$ month. In pulmonary, TB patients increased $\mathrm{Hb}$ level is used as a marker of treatment response [6]. This research aims to determine the condition of $\mathrm{Hb}$ level after the initial phase of ATD usage in TB patients.

\section{METHODS}

This research was conducted with an accidental sampling method at pulmonary polyclinic RSUD Dr. M. Yunus Bengkulu in December 2017-
June 2018. The sample of this study consisted of 38 TB patients after the initial phase of ATD usage. Before taking $3 \mathrm{ml}$ blood samples, provided the patient informed consent. The sample was measured by Coulter Act-Diff Hematology Analyzer.

\section{RESULTS AND DISCUSSION}

Based on research that has been done in hospitals Dr. M. Yunus Bengkulu in 2018, Hb level was obtained in TB patients after taking the ATD in the initial phase which showed that from 38 patients with were 22 patients (58\%) of who had below normal $\mathrm{Hb}$ level and 16 people (42\%) have normal $\mathrm{Hb}$ levels. The $\mathrm{Hb}$ levels of respondents below normal are caused by infection TB and side effects of ATD especially rifampicin, isoniazid, and pyrazinamide that can cause anemia hemolytic nausea, vomiting, and no appetite [7]. The treatment of choice for the initial phase is the daily use of isoniazid, rifampicin, pyrazinamide, and ethambutol. The combination of ATD during an initial phase is designed to reduce the bacteria population rapidly and to prevent the drug-resistant bacteria [5]. Many studies about the effect of antitubercular drugs to $\mathrm{Hb}$ level have done in Indonesia and they have the same result, there is the $\mathrm{Hb}$ level decrease after antitubercular drugs usage $[2,6,7]$.

The results of this study showed that patients with TB who had undernormal $\mathrm{Hb}$ level in the elderly $46-55$ years old as many as 10 patients $(26 \%)$ and the final age of $56-65$ years as many as 5 patients $(13 \%)$, this is due to the side effects of ATD the initial phase consumed daily. Research conducted in Korea on TB patients showed results from 880 TB patients, 281 (31.9\%) showed symptoms of anemia. Anemia is also common in women and older age [10]. At the age of the elderly life cycle is characterized by the decline in the various functions of organs, which is characterized by the more vulnerable the body against various attacks of disease. This is due to the increasing age that changes in the structure and function of cells, tissues, and organs.

Body mass index (BMI) is a simple measuring instrument to monitor nutritional status [11]. Nutritional status has a correlation positive with $\mathrm{Hb}$ concentration, meaning that a person's nutritional status is getting 
Table 1: Characteristic and levels $\mathrm{Hb}$ of TB patients after consuming initial phase of ATD

\begin{tabular}{|c|c|c|c|}
\hline \multirow[t]{2}{*}{ Variable } & \multicolumn{2}{|c|}{ Hb } & \multirow[t]{2}{*}{$\mathbf{p}$} \\
\hline & Normal & Abnormal & \\
\hline \multicolumn{4}{|l|}{ Sex } \\
\hline Male & $7(18)$ & $12(32)$ & \\
\hline Female & $9(24)$ & $10(26)$ & \\
\hline \multicolumn{4}{|l|}{ Age } \\
\hline$<45$ & $6(43)$ & $8(57)$ & 0.312 \\
\hline $45-55$ & $8(21)$ & $10(26)$ & \\
\hline $56-65$ & $1(3)$ & $5(13)$ & \\
\hline$>65$ & $0(0)$ & $0(0)$ & \\
\hline \multicolumn{4}{|l|}{ BMI } \\
\hline$<18$ & $0(0)$ & 11(100) & 0.001 \\
\hline $18-25$ & $16(59.3)$ & $11(40.7)$ & \\
\hline$>25$ & $0(0)$ & $0(0)$ & \\
\hline
\end{tabular}

TB: Tuberculosis, HB: Hemoglobin, ATD: Antitubercular drugs

worse than the lower the Hb level of the person [12]. From the research data, TB patients with BMI $<18$ all had abnormal Hb levels of $11(100 \%)$ patients, whereas patients with BMI 18-25 had 11 (40.7\%) patients who had abnormal $\mathrm{Hb}$ levels and in this study found the correlation $\mathrm{Hb}$ level with intima-media thickness $(\mathrm{p}=0.001)$. Hemoglobin levels of TB patients below normal are due to malnutrition especially iron which is part of the $\mathrm{Hb}$ molecule. Reduced iron can lead to reduced hemoglobin synthesis resulting in lower hemoglobin levels. Things that can reduce the occurrence of $\mathrm{Hb}$ levels below normal values are by way of initial phase TB patients consuming foods containing iron such as red meat, egg yolks, fish, vegetables (spinach, cassava leaves, kale, and mustard), and soybeans [12].

\section{CONCLUSION}

$\mathrm{Hb}$ levels in TB patients who consumed the initial phase of ATD were found to be mostly under normal.

\section{ACKNOWLEDGMENT}

This research was supported by Ministry of Health Indonesia Republic.

\section{CONFLICTS OF INTEREST}

The authors declare that they have no conflicts of interest.

\section{AUTHORS' CONTRIBUTIONS}

First author SW arranges ideas and conducts $\mathrm{Hb}$ examination. The second author ZM collects literature and analyzes the results of research and manuscripts of articles.

\section{REFERENCES}

1. World Health Organization. Global Tuberculosis Report 2018. Geneva: World Health Organization; 2018.

2. Shaji J, Shaikh M. Drug-resistant tuberculosis : Recent approach in polymer based nanomedicine. Int J Pharm Pharm Sci 2016;8:???

3. Dhanabal SP, Lall N, Pavithra N, Chaitanya MV. Natural products as an important leads for discovery of new antitubercular agents : A review. Indian J Pharm Pharm Sci 2015;7:2-7.

4. Fauziah I, Siahaan GE. Kadar hemoglobin $(\mathrm{Hb})$ penderita TB paru dalam masa terapi OAT (obat anti tuberkulosis) di puskesmas haji abdul halim hasan binjai. J Biol Lingkungan Ind Kesehat 2014;1:13-7.

5. The Paediatric Formulary Committee (PFC). BNF For Children. British National Formulary Publications, Royal Pharmaceutical Society of Great Britain. London: The Paediatric Formulary Committee (PFC); 2009

6. Al-Omar IA, Al-Ashban RM, Shah AH. Hematological abnormalities in Saudis suffering from pulmonary tuberculosis and their reponce to the treatment. Res J Pharmacol 2009;3:78-85.

7. Verma R, Shrivastava MG, Pathak P. Adverse drug reactions associated with first-line anti-tubercular drugs in a tertiary care hospital of central India: A study of clinical presentations, causality, and severity. Asian J Pharm Clin Res 2014;7:140-3.

8. Ulfi DN, Adang. Perbedaan kadar hemoglobin sebelum dan sesudah pemberian obat antituberkulosis fase awal. Univ Muhammadiyah Yogyakarta 20103-7.

9. Lasut NM, Rotty LW, Polii EB. Gambaran kadar hemoglobin dan trombosit pad penderita tuberkulosis paru di RSUP. DR. R. Kandou Manado. J E Clin 2014:1-6.

10. Lee SW, Kang YA, Yoon YS, Um SW, Lee SM, Yoo CG, et al. The prevalence and evolution of anemia associated with tuberculosis. J Korean Med Sci 2006;21:1028-32.

11. Supariasa ID, Bakri B, Fajar I. Penilaian Status Gizi. Jakarta: EGC; 2002. p. 48-9.

12. Thompson B. Food-Based Approaches for Combating Iron Deficiency, Nutritional Anemia. Basel: Sight and Life Press; 2007. p. 337. 